\title{
The Implications of Naturalist Illustration Image Media on Early Childhood Learning Concentration and Motivation
}

\author{
Zaenol Fajrii ${ }^{\bowtie}$, Rostanti Toba $^{2}$, Chusnul Muali1 ${ }^{1}$ Maria Ulfah $^{3}$, Fatimatus Zahro ${ }^{3}$ \\ Pendidikan Guru Madrasah Ibtidaiyah, Universitas Nurul Jadid, Paiton, Probolinggo, \\ Indonesia(1); Pendidikan Bahasa Inggris, Universitas Islam Negeri Sultan Aji Muhammad \\ Idris Samarinda (2); Pendidikan Islam Anak Usia Dini, Universitas Nurul Jadid, Paiton, \\ Probolinggo, Indonesia ${ }^{(3)}$ \\ DOI: $\underline{10.31004 / \text { obsesi.v6i4.2092 }}$
}

\begin{abstract}
Early childhood between the ages of 0 and 6 years experiences rapid growth and development. Children at this age have considerable potential that must be nurtured by providing essential knowledge, attitudes, and skills. Teachers are responsible for helping students reach their full potential through learning activities. One of them is creating exciting learning media that increases students' concentration and motivation. This study aims to adapt the use of naturalist illustration media to children's concentration and learning motivation. This research is a qualitative descriptive study using documentation, observation, and interviews. The results show that using realistic images can arouse children's curiosity, increase their focus, and encourage learning through activities and consequences. Based on the findings of this study, it can be concluded that the use of naturalist images is very suitable for early childhood education, as evidenced by the increase in children's attention and learning motivation.
\end{abstract}

Keywords: image media; naturalist illustration; concentration; learning motivation; early childhood

\begin{abstract}
Abstrak
Anak usia dini antara usia 0 dan 6 tahun mengalami pertumbuhan dan perkembangan yang pesat. Anak pada usia ini memiliki potensi yang cukup besar yang harus dibina dengan memberikan pengetahuan, sikap, dan keterampilan dasar. Guru bertanggung jawab untuk membantu siswa mencapai potensi penuh mereka melalui kegiatan pembelajaran. Salah satunya adalah menciptakan media pembelajaran yang menarik yang meningkatkan konsentrasi dan motivasi siswa. Tujuan dari penelitian ini adalah bagaimana mengadaptasi penggunaan media ilustrasi naturalis terhadap konsentrasi dan motivasi belajar anak. Penelitian ini merupakan penelitian deskriptif kualitatif dengan menggunakan dokumentasi, observasi, dan wawancara. Hasil penelitian menunjukkan bahwa penggunaan gambar naturalistik dapat membangkitkan rasa ingin tahu anak-anak, meningkatkan fokus mereka, dan mendorong pembelajaran melalui aktivitas dan konsekuensi. Berdasarkan temuan penelitian ini, dapat disimpulkan bahwa penggunaan gambar naturalis sangat cocok untuk pendidikan anak usia dini, terbukti dengan peningkatan perhatian dan motivasi belajar anak.
\end{abstract}

Kata Kunci : media gambar; ilustrasi naturalis; konsentrasi; motivasi belajar; anak usia dini

Copyright (c) 2022 Zaenol Fajri, et al.

$\triangle$ Corresponding author :

Email Address : ha54nbaharun@gmail.com (Paiton, Probolinggo, JawaTimur, Indonesia)

Received 16 November 2021, Accepted 6 January 2022, Published 25 February 2022 


\section{INTRODUCTION}

Between the ages of 0 and 6, early infancy is characterized by rapid growth and development (Khadijah \& Amelia, 2020). There is a lot of promise in early childhood that needs to be realized (Rozi \& Maulidiya, 2022). The path of life is an important stage in one's growth and development in our period (Susanto, 2017; Wahid et al., 2021). According to the opinions of numerous experts, early childhood is defined as a child between the ages of 0 and 6 who lives in the golden period (Nurmiyanti \& Candra, 2019; Wulandari \& Purwanta, 2021). At that age, sufficient stimulus is required to assist children's growth and development in achieving their development's optimal point and range (Iltiqoiyah, 2020; Umiarso \& Hidayati, 2022).

Because the physical growth of the brain occurs rapidly at this age, children under the age of eight can increase their intellect (Pura \& Wulandari, 2020; Hidayati, 2022). This development can be aided by teaching children fundamental knowledge, attitudes, and abilities. To prepare children for primary education, this promotes a variety of possibilities, including moral, social, emotional, cognitive, linguistic, physical or athletic, independence, and the arts (Wijayanti \& Efendi, 2021). The National Education System on Early Childhood Education, as stated in Article 28 paragraph 1 of Law Number 20 of 2003, "is carried out from birth to six years of age and is not a prerequisite for advancing to basic education." On the other hand, early childhood education provides direct guidance through educational stimuli (Alfina \& Anwar, 2020).

According to Utami (2020), teachers who act as educators have a positive image in society. As a result, teachers must demonstrate that they can serve as role models for the community (Fajri dan Syaidatul, 2021). Teachers have a vital role in school learning design, implementation, and evaluation (Fajri, 2019).To optimize their activities, teachers must act as planners, facilitators, observers, motivators, and friends in a variety of school events (Elfiadi, 2016).

One factor influencing learning success is learning concentration (Rosiyanah et al., 2020). Concentration, according to Slameto, is an action that involves removing something unrelated from one's head to concentrate on something else (Rozi \& Zubaidah, 2021). At the moment of learning, concentration can be employed to focus attention. The ability of a learner to focus on the object under study has an impact on their learning success (Suratun \& Tirtyanti, 2020). Concentration impacts memory; when people lose focus, they are more likely to forget things. When people are concentrated, they may recall information for a long time. Concentration in children can be improved by repeating particular activities (Rozi et al., 2021).

Learning is greatly influenced by concentration. When someone is studying, their attention will be affected, which will damage their ability to learn. Some experts also contend that early childhood learning should be an intrinsic part of all learning activities (Firdausiah, 2021). If children can concentrate, they can perform a good job. The concentration of students will influence the ability to do work optimally. However, when pupils lose concentration, it becomes difficult for them to participate in learning activities, and children become confused and have difficulties carrying out the teacher's responsibilities and activities.

Children aged 4-6 years exhibit a lack of concentration in their educational tasks. These activities include children talking with friends, children talking to themselves, student instead of youngster running alone, etc. These actions may develop due to youngsters being bored while in class. Given these circumstances, a viable strategy for increasing children's learning concentration is required (Fajri et al., 2021). Providing engaging visual media is one of the most effective strategies to improve children's attention. Naturalistic image media is a visual media that can help kids learn more effectively (Ratnaningsih \& Nastiti, 2018; Mahfuzhah \& Anshari, 2018; Sa' ad \& Istifa, 2020). The image represents the outcome of a two-dimensional depiction of an object, view, or stream of thoughts or ideas (Jubaidah, 2013). Naturalistic photos feature colours and shapes identical to those seen in nature, with no additions or subtractions (Ratnasari, 2020). The information or content offered is more thorough and easy to understand with pictures. 
Table 1. Similarities and differences between previous and current research.

\begin{tabular}{|c|c|c|c|c|}
\hline Researchers & Title & Research Result & $\begin{array}{l}\text { The equation for } \\
\text { research findings }\end{array}$ & $\begin{array}{l}\text { Study findings that } \\
\text { differ }\end{array}$ \\
\hline $\begin{array}{l}\text { Khotimah, S. } \\
\text { H., Sunaryati, } \\
\text { T., \& } \\
\text { Suhartini, S. } \\
(2021)\end{array}$ & $\begin{array}{l}\text { Penerapan Media } \\
\text { Gambar Sebagai } \\
\text { Upaya dalam } \\
\text { Peningkatan } \\
\text { Konsentrasi } \\
\text { Belajar Anak Usia } \\
\text { Dini. Hasil } \\
\text { penelitian }\end{array}$ & $\begin{array}{l}\text { The study's findings } \\
\text { show that children's } \\
\text { learning } \\
\text { concentration is } \\
\text { improving and that } \\
\text { image media can be } \\
\text { employed to } \\
\text { improve learning } \\
\text { concentration in } \\
\text { group B children at } \\
\text { RA Annajmah } \\
\text { Kebayoran Lama. }\end{array}$ & $\begin{array}{l}\text { Khotimah et al. } \\
\text { present .'s research } \\
\text { is comparable to } \\
\text { Khotimah et al. } \\
\text { previous .'s } \\
\text { research in that } \\
\text { they both look at } \\
\text { picture media and } \\
\text { how to improve } \\
\text { learning } \\
\text { concentration and } \\
\text { studies done in } \\
\text { early childhood. }\end{array}$ & $\begin{array}{l}\text { The difference between } \\
\text { Khotimah et al.'s } \\
\text { research and the } \\
\text { current research is that } \\
\text { the former only focuses } \\
\text { on image media in } \\
\text { general and the } \\
\text { concentration of early } \\
\text { childhood learning at } \\
\text { RA Annajmah } \\
\text { Kebayoran Lama. In } \\
\text { contrast, the latter } \\
\text { focuses on naturalistic } \\
\text { image media on } \\
\text { concentration and } \\
\text { learning motivation } \\
\text { and is conducted at RA } \\
\text { Nurul Qur'an the } \\
\text { Patokan Kraksaan } \\
\text { Probolinggo. }\end{array}$ \\
\hline $\begin{array}{l}\text { Ratnaningsih, } \\
\text { S., \& Nastiti, } \\
\text { G. (2018). }\end{array}$ & $\begin{array}{l}\text { Efforts to } \\
\text { Increase Student } \\
\text { Motivation by } \\
\text { Using Image } \\
\text { Media in } \\
\text { Thematic } \\
\text { Learning in } \\
\text { Elementary } \\
\text { Schools. }\end{array}$ & $\begin{array}{l}\text { The findings } \\
\text { revealed that } \\
\text { employing visual } \\
\text { media to learn } \\
\text { could boost } \\
\text { children's } \\
\text { motivation in } \\
\text { thematic learning in } \\
\text { elementary schools. }\end{array}$ & $\begin{array}{l}\text { Ratnaningsih, S., } \\
\text { and Nastiti, G.'s } \\
\text { research are } \\
\text { similar. The } \\
\text { current study } \\
\text { looks at picture } \\
\text { media as well as } \\
\text { enhancing } \\
\text { learning } \\
\text { motivation. }\end{array}$ & $\begin{array}{l}\text { The difference between } \\
\text { Ratnaningsih, S., and } \\
\text { Nastiti, G.'s research } \\
\text { and the current study } \\
\text { is that the former } \\
\text { looked at general } \\
\text { picture media and } \\
\text { primary school kids' } \\
\text { learning motivation. In } \\
\text { contrast, the latter } \\
\text { looked at naturalistic } \\
\text { picture media and } \\
\text { concentration and } \\
\text { learning motivation } \\
\text { and is conducted at RA } \\
\text { Nurul Qur'an the } \\
\text { Patokan Kraksaan } \\
\text { Probolinggo. }\end{array}$ \\
\hline $\begin{array}{l}\text { Aristia, K., } \\
\text { Nasryah, C. } \\
\text { E., \& Rahman, } \\
\text { A. A. (2020). }\end{array}$ & $\begin{array}{l}\text { Efektifitas } \\
\text { Penggunaan } \\
\text { Media } \\
\text { Pembelajaran } \\
\text { Celengan Gambar } \\
\text { Untuk } \\
\text { Meningkatkan } \\
\text { Hasil Belajar } \\
\text { Siswar Tema } \\
\text { Peduli Terhadap } \\
\text { Makhluk Hidup } \\
\text { Kelas IV SD A. }\end{array}$ & $\begin{array}{l}\text { The findings of a } \\
\text { study using the } \\
\text { picture piggy bank } \\
\text { learning media } \\
\text { showed that using } \\
\text { the picture piggy } \\
\text { bank learning } \\
\text { media improved the } \\
\text { learning outcomes } \\
\text { of fourth-grade } \\
\text { elementary school } \\
\text { children on the } \\
\text { theme of living } \\
\text { things, as seen by } \\
\text { the results of more } \\
\text { effective learning. }\end{array}$ & $\begin{array}{l}\text { The research of } \\
\text { Aristia et al. and } \\
\text { the current study } \\
\text { are comparable in } \\
\text { that they both look } \\
\text { at picture media. }\end{array}$ & $\begin{array}{l}\text { The difference between } \\
\text { Arista et al. research .'s } \\
\text { and the current } \\
\text { research is that the } \\
\text { former is a study of } \\
\text { picture piggy bank } \\
\text { learning media applied } \\
\text { to primary school } \\
\text { pupils. In contrast, the } \\
\text { latter studies } \\
\text { naturalistic picture } \\
\text { media's effect on } \\
\text { concentration and } \\
\text { learning motivation } \\
\text { and is conducted at RA } \\
\text { Nurul Qur'an the } \\
\text { Patokan Kraksaan } \\
\text { Probolinggo. }\end{array}$ \\
\hline
\end{tabular}


Because they are depicted through color images, naturalistic image media commonly utilized in learning will be more appealing and realistic (Baharun, 2016). Color photographs that portray the actual scene in large and small sizes between the photos, according to Laely(2013), are easier to see and capture children's attention. Color variations will pique the curiosity of children. Teachers can use various mediums to improve children's engagement, accuracy, and learning order.

Learning motivation is a prevalent issue in developing children's potential in education. Some educators overlook the importance of early childhood learning motivation (Oktavia \& Latifah, 2022). Educators are more likely to focus on students' accomplishments, values, and skills than learning. Passion and curiosity about how to help children attain their full potential are also vital foundations for understanding the repercussions of their development. Children's motivation, passion, and curiosity are essential aspects of their educational advancement. As a result, early childhood learning is a foundation of education that requires more attention to serve as the first foundation for future learning .

Children aged 4-6 years had trouble concentrating and encouraging themselves to learn, according to observations and interviews conducted on August 2, 2021, before researching RA Nurul Qur'an Patokan Kraksaan Probolinggo. Because the graphics used in learning include a variety of colors, they can increase children's motivation and concentration to study (Khotimah et al., 2020). Until now, learning at RA Nurul Qur'an has solely used media games in the schoolyard; media is rarely used in the classroom. Teachers are advised to employ engaging media to excite children's attention, boost concentration, and enthusiasm to learn due to the occurrence at RA Nurul Qur'an. As a result, a lifelike illustration image is a good choice for improving focus and drive to learn. As a result, the "Use of Naturalistic Image Media on Motivation and Concentration of Early Childhood Learning at RA Nurul Qur'an Patokan Kraksaan Probolinggo" will be discussed in this research. Other researchers researched with titles relevant to the author before this study. Still, there were some changes in the item, location, research factors, and period of the study (table 1)

\section{METHODOLOGY}

The study is a qualitative study that provides descriptive information or an explanation of something linked to the facts in the field (Firthian \& Putry, 2021). This study describes the implementation of naturalistic image media on the motivation and learning concentration of children aged 4-6 years at RA Nurul Qur'an Patokan Kraksaan Probolinggo in the even semester of the 2021/2022 academic year. Researchers must be intimately involved in the research subject when using picture media to identify early childhood concentration in learning. Several naturalist photos following the learning material and created by the teacher, primarily the outcomes of color printouts retrieved from the internet, are utilized as image media. As a result, researchers will connect directly with research participants.

Observation sheets, interviews, and documentation were used to collect data. Interviews were done through dialogues or questions and answers to collect more detailed information from direct data sources (Rahmina et al., 2020). After completing learning utilizing naturalistic visual media, the teacher and many students did interviews. By evaluating each behavior, participant observation makes the data acquired more complete. Documentation is done to gather records of events, such as images, written artifacts, or other theories regarding the research subject (Aristia et al., 2020).

Starting with the outcomes of interviews, observations, and documentation, the methods to systematically locate, record, and arrange guest research results are known as data analysis. This data analysis can be done concurrently with data gathering and then resumed once the data collection is finished.

\section{RESULTS AND DISCUSSION}


This study covers the data acquired through interviews, observations, and documentation while presenting the findings. This is accomplished in three stages: preparation, execution, and evaluation. This proposal attempts to make it easier for teachers to teach based on their qualifications. The purpose is to narrow the focus of the learning process so that the learning objectives can be met.

Following is a brief explanation of the results of interviews with teachers and students at RA Nurul Qur'an Patokan Kraksaan Probolinggo after the implementation of learning via illustrated media on the concentration and learning motivation of early childhood: 1) Teachers can work well and smoothly in carrying out learning using naturalistic defined media; at the start of learning, the teacher provides direction on learning objectives and how to use natural illustration media; students appear more focused in learning so they are easily directed by the teacher; teachers can easily make early children concentrate on learning, especially in understanding the material they are learning. 2) Based on the findings of interviews with early childhood after studying, early childhood enjoys learning because the children use attractive and intriguing visuals.

Teachers, as educators, play a critical role in developing visual media lesson plans (Zamroni et al., 2021). According to one teacher, pupils' literacy will increase if they participate in skill development activities that focus on the learning process through media. A Learning Implementation Plan (RPP) must be created by the teacher and applied to learning.

Children's educational books are an example of visual media. Schools use the media to help students meet their learning objectives. Naturalistic photos and books, with photographs ordered according to the topic of discussion, are used by the instructor to produce learning media according to the lesson plan (Figure 1).

A quiet school setting and excellent teachers, in addition to the media employed, will contribute to a more comfortable learning environment. The atmosphere of the learning process is the joy of learning, which means that students may devote their full attention to studying. Education entails listening to the teacher's information lectures and getting the kids to participate. The availability of learning resources in images demonstrates children's active role. While some photographs are already colored and appear natural, others are colorless. Children can be encouraged to concentrate on learning by using media that has been scientifically explained (Khotimah et al., 2021). Increased emphasis on the child achieves learning objectives. This will improve children's learning motivation and performance if they are taught continually.

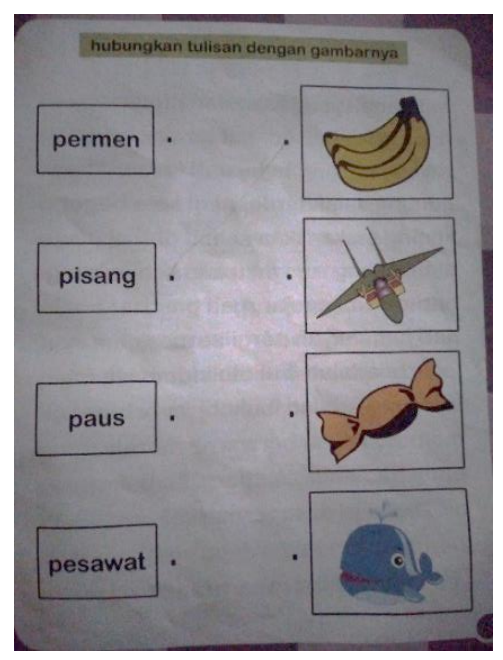

Figure 1. A naturalist reading theme illustration (documentation of researchers in the field) 
The learning implementation plan is implemented when the learning has been completed. As one instructor put it, understanding necessitates the use of a teacher to carry out lesson plans. In this instance, the teacher must be as effective as possible to optimize attentiveness and effectively develop skills. Teachers can also examine children's conduct daily to ensure that student learning is consistent throughout the learning process. According to the teacher, professional teachers, adequate facilities, and the role of parents in supporting children's education are all aspects that can aid in this learning (Agusriani \& Fauziddin, 2021). The teacher preoccupied with technology and appears less disciplined in the classroom can hinder learning.

Teachers, as educators, must take an active role in implementing learning models to assist pupils in focusing on their studies. This will have an impact on student learning outcomes. As a result, visual media usage in the classroom improves children's concentration. There are various factors to consider while choosing picture media, including each student's personality, the features of the material, and the child's learning environment.
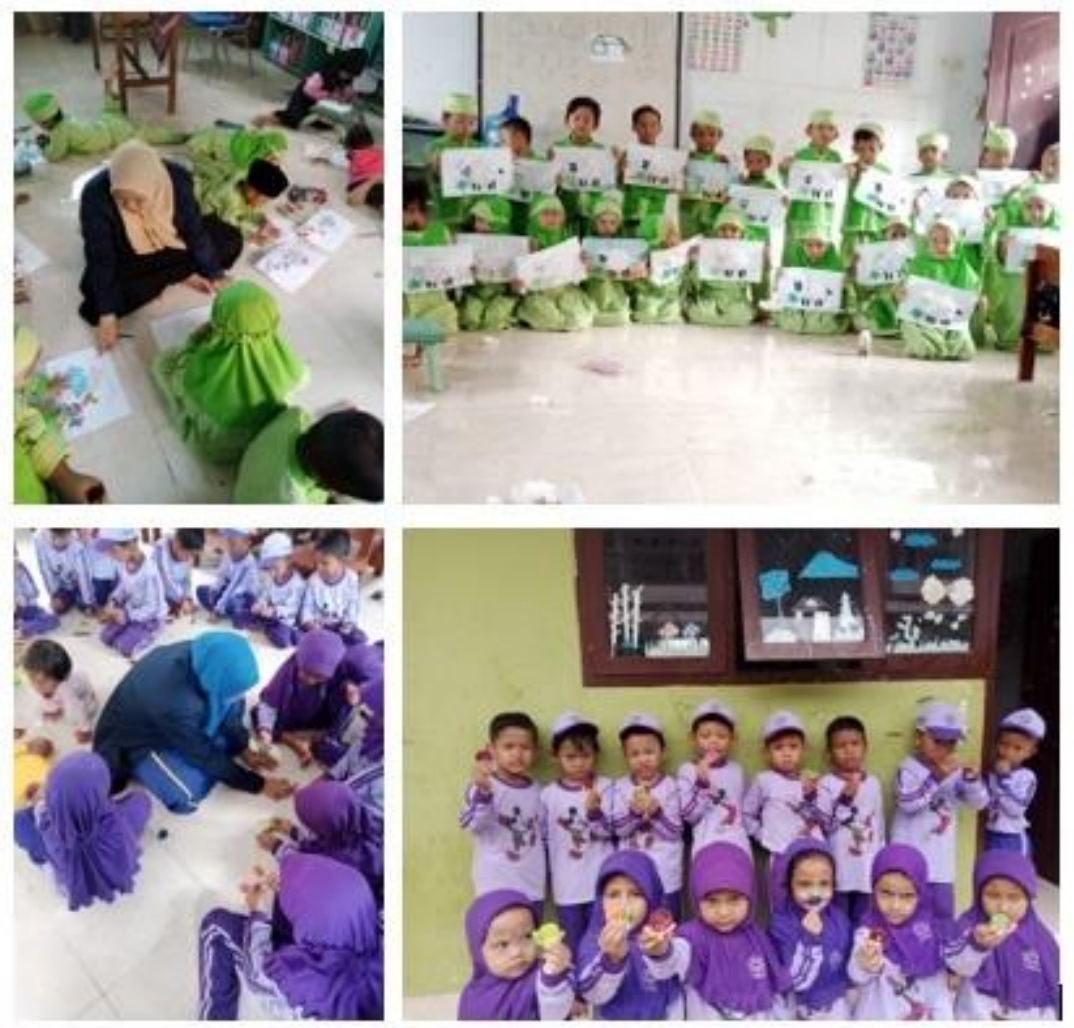

Figure 2. shows the naturalist illustration drawing method's process of learning. (documentation of researchers in the field)

Naturalist illustrations are used in the learning process to boost learning concentration. Concentration can be defined as focusing on problems that need to be solved during the learning process. The use of naturalistic illustrated media to drive attention and learning is effective based on the findings. Teachers take an active role in instructing and instructing students. Teachers are also highly imaginative when it comes to assigning tasks that aid in the growth of youngsters (Figure 2).

On the other hand, some aspects of learning through visual media are not optimal. Some students place an excessive amount of emphasis on realistic images and ignore other learning tools. You'll notice a lot of photos of colorless balls in the example math problem, for example. Children's learning objectives range from one to ten, although the books used in early childhood are still black and white, as seen Figure 3. 


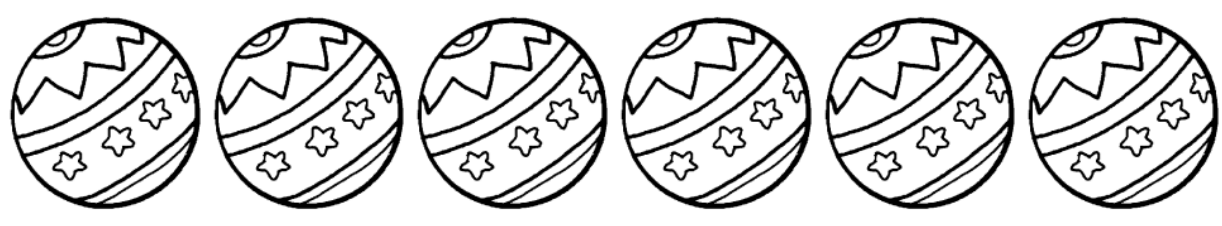

Figure 3. Shows an example of a colorless ball.

Some children focus too much on coloring and overlook the computation results when presented with a colorless picture like the one above, but this does not lower each child's concentration. The other child must insist on picking the color. This occurs when the teacher is too preoccupied with implementing the lesson plans to notice each child's condition. Because the teacher is less responsive and attentive, there is also a gap between the teacher and the child. Teachers must act as collaborators, mentors, and parents to their students. Other tactics, on the other hand, can eventually overcome this.

The teacher explains how the evaluation is done to see how much the youngster can focus and stimulate the learning process. The assessment results are used to decide the behavior of the following teacher in connection to the child's ability and inability to comprehend what he has learned. A teacher mentioned that a child's assessment could take a different format. Children can be assessed at any time during the learning process. Another teacher stated that the evaluation was done not only to examine the program's success but also to assess the development and advancement of the children in their learning.

The evaluation is carried out to gather precise information regarding children's learning abilities. The study's findings were utilized to rank pupils who met the minimum integrity requirements (KKM). Daily examinations, homework, and final exams are used to assess students. Memorization, how to count photos, how to read, and other types of questions are included in the evaluation structure. Each session concludes with an assessment of visual media usage in the form of realistic representations. This is done to determine whether or not the child has grasped the information. Teachers can use this exam to determine each child's pace and delay as they progress through various lessons. Learning resources for late children will be repeated due to these findings, while other materials will be handed to early childhood. Teachers are evaluated as educators in addition to their students. The purpose is to assess a teacher's performance and determine whether or not they are capable of carrying out their responsibilities appropriately. Children's failure to learn can be caused by a variety of causes, according to Fridani et al. (2017), including the use of inappropriate media, uninteresting learning, or inappropriate methodologies.

\section{CONCLUSION}

It can be inferred from the research and analysis of the use of naturalistic picture media for motivation and concentration in early infancy that the design, implementation, and evaluation were successfully done. The learning outcomes demonstrated an increase in children's attentiveness and learning drive. If youngsters are motivated to focus and actively learn, learning objectives will be met. Achieving these objectives will result in exceptional graduates who will help to increase school quality. The teacher's position in education can be used by acting as a mediator, facilitator, and motivator in the classroom to become more engaged in learning. The teacher uses a daily test, homework, and final exam schedule for evaluation.

\section{ACKNOWLEDGEMENTS}

The researcher would like to thank the Chancellor of Nurul Jadid University, Dean of the Faculty of Islamic Religion, Nurul Jadid University who has provided guidance, direction and motivation, so that this research was completed properly. The researcher also thanks the 
editorial team of the Obsession Journal who has provided the opportunity for researchers to publish their manuscripts in this good journal.

\section{REFERENCES}

Agusriani, A., \& Fauziddin, M. (2021). Strategi Orangtua Mengatasi Kejenuhan Anak Belajar dari Rumah Selama Pandemi Covid-19. Jurnal Obsesi : Jurnal Pendidikan Anak Usia Dini, 5(2), 1729-1740. https://doi.org/10.31004/obsesi.v5i2.961

Alfina, A., \& Anwar, R. N. (2020). Manajemen Sekolah Ramah Anak Paud Inklusi. Al-Tanzim: Jurnal Manajemen Pendidikan Islam, 4(1), 36-47. https://doi.org/10.33650/altanzim.v4i1.975

Aristia, K., Nasryah, C. E., \& Rahman, A. A. (2020). Efektifitas Penggunaan Media Pembelajaran Celengan Gambar Untuk Meningkatkan Hasil Belajar Siswa Tema Peduli Terhadap Makhluk Hidup Kelas IV SD A. Jurnal Ilmiah Pendidikan, 1(2), 16-25. https:// doi.org/10.51276/edu.v1i2.33

Baharun, H. (2016). Pengembangan Media Pembelajaran PAI Berbasis Lingkungan Melalui Model ASSURE. Cendekia: Journal of Education and Society, 14(2), 231-246. https://doi.org/10.21154/cendekia.v14i2.610

Elfiadi. (2016). Bermain Dan Permainan Bagi Anak Usia Dini. ITQAN: Jurnal Ilmu-Ilmu Kependidikan, VII(1), 51-60.

Fajri Zaenol; Syaidatul Mukaroma. (2021). Pendidikan Akhlak Perspektif Al Ghazali Dalam Menanggulangi Less Moral Value. Edureligia; Jurnal Pendidikan Agama Islam, 5(1), 31-47.

Fajri, Z. (2019). Model Pembelajaran Discovery Learning dalam Meningkatkan Prestasi Belajar Siswa SD. Jurnal Ika Pgsd Unars, 7(2), 1-10. https://doi.org/10.36841/pgsdunars.v7i2.478

Fajri, Z., Baharun, H., Muali, C., Shofiatun, Farida, L., \& Wahyuningtiyas, Y. (2021). Student's Learning Motivation and Interest

Firdausiah, F. (2021). Implementation of Role-Playing Games in Overcoming Introverted Children. AL-ISHLAH: Jurnal Pendidikan, 13(2), 1394-1402. https://doi.org/10.35445/alishlah.v13i2.629

Firthian, R., \& Putry, D. . (2021). Penciptaan Ilustrasi Prabu Siliwangi sebagai Media Pelestarian Budaya dan Sejarah di Jawa Barat. Paravisual: Jurnal Desain Komunikasi Visual Dan Multimedia, 1(1), 1-8.

Fridani, L., Wulan, S., \& Pujiastuti, S. I. (2017). Evaluasi Perkembangan Anak Usia Dini.

Iltiqoiyah, L. (2020). Manajemen Pembelajaran melalui Pendekatan BCCT dalam Meningkatkan Multiple intelligences Anak. Jurnal Obsesi : Jurnal Pendidikan Anak Usia Dini, 5(2), 13681381. https://doi.org/10.31004/obsesi.v5i2.781

Jubaidah. (2013). Peningkatan Aktivitas Belajar Siswa Melalui Media Gambar pada Pembelajaran Bahasa Indonesia.

Khadijah, \& Amelia, N. (2020). Asesmen Perkembangan Kognitif Anak Usia 5-6 Tahun. Al Athfaal: Jurnal Ilmiah Pendidikan Anak Usia Dini, 3(1), 69-82. https://doi.org/10.24042/ajipaud.v3i1.6508

Khotimah, S. H., Sunaryati, T., \& Suhartini, S. (2020). Penerapan Media Gambar Sebagai Upaya dalam Peningkatan Konsentrasi Belajar Anak Usia Dini. Jurnal Obsesi : Jurnal Pendidikan Anak Usia Dini, 5(1), 676. https://doi.org/10.31004/obsesi.v5i1.683

Khotimah, S. H., Sunaryati, T., \& Suhartini, S. (2021). Penerapan Media Gambar Sebagai Upaya dalam Peningkatan Konsentrasi Belajar Anak Usia Dini. Jurnal Obsesi : Jurnal Pendidikan Anak Usia Dini, 5(1), 676-685. https://doi.org/10.31004/obsesi.v5i1.683

Laely, K. (2013). Peningkatan Kemampuan Membaca Permulaan Melalui Penerapan Media Kartu Gambar. Jurnal Pendidikan Usia Dini, 7(2), 1-20.

Mahfuzhah, H., \& Anshari, A. (2018). Media Publikasi Humas Dalam Pendidikan. Al-Tanzim: Jurnal Manajemen Pendidikan Islam, 2(2), 137-149. https://doi.org/10.33650/al$\underline{\operatorname{tanzim} . v 2 \mathrm{i} 2.395}$ 
Nurmiyanti, L., \& Candra, B. Y. (2019). Kepemimpinan Transformasional dalam Peningkatan Mutu Pendidikan Anak Usia Dini. Al-Tanzim: Jurnal Manajemen Pendidikan Islam, 3(2), 13-24. https://doi.org/10.33650/al-tanzim.v3i2.646

Oktavia, D. M., \& Latifah, I. (2022). Pengaruh Bowling Kaleng terhadap Motivasi Belajar Anak. 19.

Pura, D. N., \& Wulandari, A. (2020). Peningkatan Konsentrasi Anak Melalui Metode Eksperimen Membuat Lava Gunung Merapi. Early Child Research and Practice, 1(1), 22-27. https://doi.org/10.33258/ecrp.v1i01.1073

Rahmina, W., Nurtiani, A. T., \& Amelia, L. (2020). Analisis Kegiatan-Kegiatan Peningkatan Kecerdasan Interpersonal Anak Kelompok A di TK Cut Meutia Banda Aceh. Jurnal Ilmiah Mahasiswa Pendidikan, 1(1).

Ratnaningsih, S., \& Nastiti, G. (2018). Efforts to Increase Student Motivation by Using Image Media in Thematic Learning in Elementary Schools. Al Ibtida: Jurnal Pendidikan Guru MI, 5(2), 275-286. https://doi.org/10.24235/al.ibtida.snj.v5i2.3397

Ratnasari, A. A. (2020). Perancangan Buku Interaktif (Busy Book) sebagai Media Pelengkap Edukasi Hewan dan Tumbuhan dalam Meningkatkan Kecerdasan Naturalis Anak Usia Dini. In Universitas Pasundan (Vol. 4, Issue 1).

Rosiyanah, R., Yufiarti, Y., \& Meilani, S. M. (2020). Pengembangan Media Stimulasi Sensori Anak Usia 4-6 Tahun Berbasis Aktivitas Bermain Tujuh Indera. Jurnal Obsesi : Jurnal Pendidikan Anak Usia Dini, 5(1), 941-956. https:// doi.org/10.31004/obsesi.v5i1.758

Rozi, F., \& Maulidiya, H. (2022). The â€TM Sekolah Sak Ngajine â€TM Program; The Habit of loving the Qur âTTM an from an Early Age based on Tilawati. Jurnal Obsesi : Jurnal Pendidikan Anak Usia Dini, 6(3), 1667-1676. https://doi.org/10.31004/obsesi.v6i3.1636

Rozi, F., \& Zubaidah. (2021). Penerapan Media Gambar Berseri dalam Meningkatkan Bahasa Ekspresif Anak Usia Dini. Murobbi; Jurnal Ilmu Pendidikan, 5(2), 257-272.

Rozi, F., Mubarak, A. F., \& Humaidah. (2021). Penggunaan Media Permainan Bola Angka Terhadap Kemampuan Mengenalkan Konsep Bilangan 1-10 pada Anak. 10(2), 266-277.

Sa'ad, M., \& Istifa, F. A. (2020). Simulakra Bahasa Agama Da'i Milenial di Media "TikTok." Jurnal Komunikasi Islam, 10(2), 235-255. https://doi.org/10.15642/jki.2020.10.2.235-255

Suratun, \& Tirtyanti, S. (2020). Pengaruh Brain Gym Terhadap Konsentrasi Belajar Siswa. Jurnal Keperawatan Muhammadiyah, 5(1), 101-105. https://doi.org/10.30651/jkm.v5i1.3625

Susanto, A. (2017). Pendidikan Anak Usia Dini. PT. Bumi Aksara.

the Effectiveness of Online Learning during COVID-19 Pandemic. Journal of Physics: Conference Series, 1899(1). https://doi.org/10.1088/1742-6596/1899/1/012178

Umiarso, \& Hidayati, N. (2022). Improving Children â€TM s Cognitive Intelligence Through Literacy Management. Jurnal Obsesi: Jurnal Pendidikan Anak Usia Dini, 6(3), 1588-1598. https://doi.org/10.31004/obsesi.v6i3.1817

Umiarso, Zamroni, \& Hidayati, N. (2022). Improving Children â€TM s Cognitive Intelligence Through Literacy Management. Jurnal Obsesi : Jurnal Pendidikan Anak Usia Dini, 6(3), 1588-1598. https://doi.org/10.31004/obsesi.v6i3.1817

Utami, Indah Hari, U. H. (2020). Kompetensi Profesional Guru Dalam Penerapan Pembelajaran Tematik Di Sd Negeri Maguwoharjo 1 Yogyakarta. Pionir (Jurnal Pendidikan), 8(2), 121139.

Wahid, A. H., Rozi, F., Baharun, H., Hidayati, W., \& Bon, A. T. (2021). Information Technology in the Development of Language Aspects of Early Childhood.

Wijayanti, W., \& Efendi, M. (2021). Efektivitas Model Pakem dalam Meningkatkan Konsentrasi Belajar Anak Usia Dini. Wisdom: Jurnal Pendidikan Anak Usia Dini, 2(1), 92-109. https://doi.org/10.21154/wisdom.v2i1.2485

Wulandari, H., \& Purwanta, E. (2021). Pencapaian Perkembangan Anak Usia Dini di Taman Kanak-kanak selama Pembelajaran Daring di Masa Pandemi Covid-19. Jurnal Obsesi: Jurnal Pendidikan Anak Usia Dini, 5(1), 452-462. https:// doi.org/10.31004/obsesi.v5i1.626

Zamroni, Amir, \& Saleha, L. (2021). Pengelolaan APE Berbahan Limbah untuk Meningkatkan Kecerdasan Kognitif Anak. Jurnal Obsesi: Jurnal Pendidikan Anak Usia Dini, 5(2), 13821395. https://doi.org/10.31004/obsesi.v5i2.763 